\title{
Respiratory disease mortality patterns among South African iron moulders
}

\author{
F SITAS, ${ }^{1 *}$ ALLISON J DOUGLAS, ${ }^{2}$ E C WEBSTER ${ }^{3}$
}

From the Epidemiology Unit, ${ }^{1}$ National Centre for Occupational Health, PO Box 4788, Johannesburg 2000, South Africa, Division of Medical Statistics and Epidemiology, ${ }^{2}$ London School of Hygiene and Tropical Medicine, London WCIE 7HT, UK, and Department of Sociology, ${ }^{3}$ University of the Witwatersrand, Johannesburg 2001, South Africa

ABSTRACT To assess the influence of foundry exposure on malignant and non-malignant respiratory disease, the proportional mortality ratio (PMR) was used to compare the cause of death distributions of the 578 dead members of the Iron Moulders Society of South Africa, recipients of the union's death benefit fund between 1961 and 1983. Comparisons were made with the age and period specific white male deaths. For the 419 members where job information was available, the influence of occupation (journeyman, production moulder) was assessed using different techniques-the relative proportional mortality ratio (RPMR), the mortality odds ratio (MOR), and the proportional cancer mortality ratio (PCMR) for comparison. Excess PMRs were found for cancer of the trachea, bronchus, and lung $(1.71, p=0.03$; Poisson one sided test) for those over 65 and for non-malignant respiratory disease $(1.58, \mathrm{p}=0.01)$ and for injuries and poisonings $(2.61, \mathrm{p}<0.0001)$ in those under 65. Reduced PMRs were found for all cancers $(0.75, \mathrm{p}=0.03)$ and all circulatory disease $(0.91$, $p=0 \cdot 12$ ) in those under 65 . When comparing job types, raised risks were obtained for journeymen using all methods (RPMR, MOR, PCMR) but the small cell sizes rendered the results non-significant. The raised PMRs due to respiratory disease are unlikely to be due to smoking because of a poor association with other causes of death related to smoking. A more likely explanation is that these excess rates for malignant and non-malignant respiratory disease are due to exposure to the foundry environment. Of additional concern are the high PMRs due to injuries and poisonings, which could be related to the high accident rates in the iron and steel industry.

Epidemiological evidence concerning the positive association between foundry exposure and respiratory disease (malignant and non-malignant) has been accumulating since the first studies conducted some 50 years ago. Of particular concern are silica and other particulate dusts and suspected carcinogens such as polyaromatic hydrocarbons and benzo(a)pyrenes, both commonly found in foundries. ${ }^{12}$ The association between exposure to these compounds and respiratory and other diseases has been reviewed extensively elsewhere. ${ }^{2-4}$

In countries where detailed statistical and employment records are kept the standardised mortality ratio (SMR) has been the method of choice, using national or local rates to derive the expected age

*Current address: Cancer Epidemiology and Clinical Trials Unit, Imperial Cancer Research Fund, Radcliffe Infirmary, Oxford, OX2 6HG.

Accepted 18 April 1988 cause specific comparison rates. When there is no available information on the population at risk-for instance, the records of death benefit funds-use may be made of the proportional mortality ratio (PMR) as an approximation to the SMR. ${ }^{5} \mathrm{~A}$ recent development in occupational disease mortality studies has been to treat the data as a variant of a case-control study, using the relative PMR, the mortality odds ratio (MOR), and proportional cancer mortality ratio (PCMR) instead of the PMR approach. ${ }^{6-8}$ Several studies concerning foundry and other occupational exposures have been conducted using these methods. . $^{-12}$

The availability of the records of a death benefit fund of a predominantly white closed shop craft union, the Iron Moulders Society of South Africa (IMS-SA), presented the opportunity to compare the PMR, MOR, and PCMR in order to assess the effect of type of job on malignant and non-malignant respiratory and other causes of death. 


\section{Subjects}

\section{UNION RECORDS}

The IMS-SA was established in 1896 and currently has about 3000 members. Originally it drew on immigrant Europeans and Afrikaners. Changes in production volumes, production methods, and demands for cheaper non-white labour led to the introduction of "coloured" members (workers of mixed racial backgrounds) into the industry during the second world war and subsequently into the union in 1945. In a similar fashion black workers were introduced to moulding in the 1950s and were incorporated into the union in $1979 .^{1314}$ The IMS-SA death benefit fund was set up in 1961 to provide funeral and other death benefits for members and their widows. Benefits applied to those who had been members for over one year. After ten years' membership members may leave the trade but still continue to contribute to the death benefit fund and be eligible for benefits. Members joined up for an apprenticeship period of six years (now reduced to four) in order to become skilled journeymen. Journeymen are engaged primarily in designing and constructing moulds. Production moulders do not have to undergo any apprenticeship and are primarily engaged in manufacturing moulds from preformed patterns. Both are engaged in hot and cold jobs and journeymen are more likely to become supervisors of moulding operations. Altogether 630 deaths were recorded in the minutes of the death benefit fund. Full names and all other available details were sent to the Department of the Interior which returned the death certificates containing the International Classification of Disease Code for the underlying cause of death. Twenty six of the deaths were of non-white members. Because of low numbers and poor population comparison information for non-white South Africans, they were excluded from the study. Two members out of benefit and one female member were also excluded. No full follow up was conducted to assess those who died out of benefit.

Union records included information on job type (journeyman (JM), production moulder (PM), 72.2\% complete), date of birth ( $100 \%$ complete) and year of death ( $100 \%$ complete), which allowed for stratification by age at death, year of death, and by job type.

\section{Methods}

\section{PROPORTIONAL MORTALITY ANALYSIS}

Expected proportions of cause specific deaths were calculated from the South African national death records for each year, from 1961 to 1983 using the person-years computer program. ${ }^{16}$ Results for each cause of death of interest from each five year age at death interval $(20-24,25-29 \ldots \geqslant 65)$ were accumulated. The expected deaths were calculated from the proportion of all deaths in a particular age and calendar year stratum due to the cause of death of interest in the South African population multiplied by the number of deaths from all causes in the same age and calendar year stratum in the iron moulders. The three changes in the ICD codes during 1961-83 (6th, 7th, 8th revisions) were incorporated into the program. A summary PMR for each cause of death of interest was produced by dividing the number of deaths for a particular cause by the expected number of deaths derived as previously mentioned. A Poisson one sided test of significance value was calculated. Results were stratified by age at death $(<65, \geqslant 65$, $\mathrm{n}=578$ ) and job type and age at death (journeymen $<65$, $\geqslant 65$; production moulders, $<65, \geqslant 65$, $\mathrm{n}=419)$.

\section{RPMR, MOR, AND PCMR ANALYSES}

The RPMR was calculated by comparing the proportion of deaths due to the cause of interest in one exposure category to the proportion of deaths of interest in the other category. The MOR uses the noncases unrelated to exposure risk as controls. ${ }^{7}$ For example, in lung cancer deaths due to non-malignant respiratory disease were excluded from the control group. In respiratory disease comparisons deaths from lung cancer were excluded from the control group. To assess the effect of these exclusions the MOR used two different control groups: (i) all non-cases and (ii) all non-cases without the "other" respiratory diseases of interest. In the PCMR analysis all non-cancer deaths were excluded. ${ }^{8}$ In this study, where respiratory disease comparisons are made, lung cancer was excluded from the control groups. In all instances two by two tables were constructed from the PMR results for journeymen and production moulders to determine the odds ratio (OR) between malignant or non-malignant respiratory disease and odds of job type exposure. Analysis was stratified into two age at death intervals, $20-64$ and $\geqslant 65$ years. Small cell sizes necessitated the use of Fisher's exact test ( 2 sided). ${ }^{17}$ Where the expected cell frequency exceeded 5 in all cells the chi-squared test $(1 \mathrm{df})$ with a continuity correction was used.

\section{Results}

PMR ANALYSIS

Tables 1-3 give the observed and expected numbers of deaths for the causes of death of interest with the $\mathrm{O} / \mathrm{E}$ ratio and Poisson one sided $p$ values. Table 1 is stratified by age alone, whereas tables 2 and 3 are stratified by age and job type. 
Table 1 Results of the PMR analysis: (1) stratified by age

\begin{tabular}{|c|c|c|c|c|c|c|c|c|}
\hline \multirow[b]{3}{*}{ Cause } & \multicolumn{8}{|c|}{ Age (years) } \\
\hline & \multicolumn{4}{|c|}{$20-64(n=372)$} & \multicolumn{4}{|c|}{$\geqslant 65(n=206)$} \\
\hline & Obs & $\operatorname{Exp}$ & $O / E$ & $\begin{array}{l}\text { Poisson } \\
1 \text { sided } p^{*}\end{array}$ & Obs & $\operatorname{Exp}$ & $O / E$ & $\begin{array}{l}\text { Poisson } \\
1 \text { sided } p^{*}\end{array}$ \\
\hline $\begin{array}{l}\text { All cancer } \\
\text { Ca buccal, lip, pharynx } \\
\text { Ca larynx } \\
\text { Ca trachea, bronchus, lung } \\
\text { Ca oesophagus } \\
\text { Ca stomach } \\
\text { Ca intestines, rectum } \\
\text { Ca prostate } \\
\text { All non-malignant respiratory } \\
\text { Respiratory tuberculosis } \\
\text { All circulatory } \\
\text { All poisonings, accidents }\end{array}$ & $\begin{array}{r}40 \\
3 \\
2 \\
13 \\
3 \\
5 \\
1 \\
1 \\
39 \\
4 \\
152 \\
78\end{array}$ & $\begin{aligned} 53 \cdot 7 \\
2 \cdot 26 \\
1.22 \\
15.48 \\
1 \cdot 78 \\
5 \cdot 51 \\
4 \cdot 26 \\
1.48 \\
24 \cdot 7 \\
2.05 \\
167.43 \\
29.91\end{aligned}$ & $\begin{array}{l}0.75 \\
1.33 \\
1.64 \\
0.84 \\
1.69 \\
0.91 \\
0.24 \\
0.68 \\
1.58 \\
1.95 \\
0.91 \\
2.61\end{array}$ & $\begin{array}{l}0 \cdot 03 \\
0 \cdot 39 \\
0 \cdot 35 \\
0 \cdot 31 \\
0 \cdot 26 \\
0 \cdot 52 \\
0 \cdot 07 \\
0 \cdot 56 \\
0 \cdot 005 \\
0 \cdot 15 \\
0 \cdot 12 \\
0.000\end{array}$ & $\begin{array}{r}33 \\
0 \\
0 \\
15 \\
1 \\
3 \\
2 \\
5 \\
34 \\
3 \\
98 \\
7\end{array}$ & $\begin{array}{r}36 \cdot 12 \\
1.05 \\
0.55 \\
8.75 \\
1.13 \\
4.71 \\
3.53 \\
5.64 \\
28 \cdot 1 \\
0.75 \\
109.9 \\
8.87\end{array}$ & $\begin{array}{l}0.91 \\
\overline{-} \\
\overline{1} \cdot 71 \\
0.89 \\
0.64 \\
0.57 \\
0.89 \\
1.21 \\
3.98 \\
0.89 \\
0.79\end{array}$ & $\begin{array}{l}0 \cdot 34 \\
- \\
0 \cdot 03 \\
0 \cdot 69 \\
0 \cdot 31 \\
0 \cdot 32 \\
0 \cdot 51 \\
0 \cdot 15 \\
0.04 \\
0 \cdot 14 \\
0 \cdot 34\end{array}$ \\
\hline
\end{tabular}

*In the direction of the observed value.

CANCER OF THE TRACHEA, BRONCHUS, AND

LUNG (ICD 162-166)

An increased PMR for malignant respiratory disease was found for the older iron moulders (aged over 65) $(\mathrm{O} / \mathrm{E}=1.71, \mathrm{p}=0.03)$ and a decreased PMR among the younger iron moulders (under 65$)(\mathrm{O} / \mathrm{E}=0.84$, $p=0.31$ ). When stratified by job type and age at death, raised PMRs were found for both older journeymen and production moulders (journeymen $<65$ $\mathrm{O} / \mathrm{E}=1 \cdot 14, \mathrm{p}=0.38 ;$ journeymen $\geqslant 65 \mathrm{O} / \mathrm{E}=1.94$, $\mathrm{p}=0.025 ;$ production moulders $\geqslant 65 \mathrm{O} / \mathrm{E}=1.62$, $\mathrm{p}=0.46)$. Young production moulders had a reduced $\operatorname{PMR}(\mathrm{O} / \mathrm{E}=0.87, \mathrm{p}=0.59)$.

\section{NON-MALIGNANT RESPIRATORY DISEASE}

(ICD 460-519.9)

Excess PMRs for non-malignant respiratory disease were found for all stratifications except for the older production moulders $(\geqslant 65 \mathrm{O} / \mathrm{E}=0.51, \mathrm{p}=0.41)$. 을 Stratified by age alone, $O / E$ values for those under $65_{3}^{-}$ were $1.58(p=0.005)$ and $1.21(p=0.15)$ for those over 65. Stratified by job type PMRs were as follows: journeymen $<65 \mathrm{O} / \mathrm{E}=1.66, \mathrm{p}=0.02$; jour $-\oplus$ neymen $\geqslant 65 \mathrm{O} / \mathrm{E}=1.35, \mathrm{p}=0.08$; production. moulders $<65 \mathrm{O} / \mathrm{E}=1 \cdot 76, \mathrm{p}=0 \cdot 11$.

\section{OTHER CAUSES OF DEATH}

Injury and poisoning (ICD 800-999)

Significantly raised PMRs for injuries and poisonings $\frac{2}{\varnothing}$ were observed for all younger categories. For those $\vec{F}$ under $65 \mathrm{O} / \mathrm{E}=2.61, \mathrm{p}<0.0001$. For journeymen $<65 \mathrm{O} / \mathrm{E}=3.38(\mathrm{p}<0.0001)$ and for production moulders $<65 \mathrm{O} / \mathrm{E}=5.94(\mathrm{p}<0.0001)$.

Circulatory disease (ICD 390-459.9)

All stratification levels except that for the younger?

Table 2 Results of the PMR analysis: stratified by age and job type: (1) journeymen

\begin{tabular}{|c|c|c|c|c|c|c|c|c|}
\hline \multirow[b]{3}{*}{ Cause } & \multicolumn{8}{|c|}{ Age (years) } \\
\hline & \multicolumn{4}{|c|}{$20-64(n=189)$} & \multicolumn{4}{|c|}{$\geqslant 65(n=142)$} \\
\hline & Obs & $\operatorname{Exp}$ & $O / E$ & $\begin{array}{l}\text { Poisson } \\
\text { I sided p* }\end{array}$ & Obs & $\operatorname{Exp}$ & $O / E$ & $\begin{array}{l}\text { Poisson } \\
\text { I sided } p^{*}\end{array}$ \\
\hline $\begin{array}{l}\text { All cancer, } \\
\text { Ca buccal, lip, pharynx } \\
\text { Ca larynx } \\
\text { Ca trachea, bronchus, lung } \\
\text { Ca oesophagus } \\
\text { Ca stomach } \\
\text { Ca intestines, rectum } \\
\text { Ca prostate } \\
\text { All non-malignant respiratory } \\
\text { Respiratory tuberculosis } \\
\text { All circulatory } \\
\text { All poisonings, accidents }\end{array}$ & $\begin{array}{r}23 \\
2 \\
0 \\
10 \\
0 \\
1 \\
1 \\
1 \\
22 \\
2 \\
78 \\
39\end{array}$ & $\begin{array}{c}29 \cdot 12 \\
1.26 \\
0.69 \\
8 \cdot 77 \\
0.96 \\
2.87 \\
2 \cdot 3 \\
0.86 \\
13 \cdot 22 \\
1.0 \\
90 \cdot 52 \\
11 \cdot 52\end{array}$ & $\begin{array}{l}0.79 \\
1 \cdot 59 \\
\overline{1 \cdot 14} \\
\overline{0.35} \\
0 \cdot 44 \\
1 \cdot 17 \\
1.66 \\
2 \cdot 01 \\
0.86 \\
3.38\end{array}$ & $\begin{array}{l}0.15 \\
0.36 \\
\overline{0.38} \\
\overline{0.22} \\
0.33 \\
0.58 \\
0.02 \\
0.26 \\
0.10 \\
0.000\end{array}$ & $\begin{array}{r}25 \\
0 \\
0 \\
12 \\
0 \\
1 \\
1 \\
4 \\
26 \\
1 \\
71 \\
3\end{array}$ & $\begin{array}{c}25.04 \\
0.7 \\
0.4 \\
6.19 \\
0.77 \\
3.16 \\
2.44 \\
3.88 \\
19.28 \\
0.46 \\
76.28 \\
6.16\end{array}$ & $\begin{array}{l}1.0 \\
- \\
\overline{1.94} \\
\overline{0.32} \\
0.41 \\
1.03 \\
1.35 \\
2.17 \\
0.93 \\
0.49\end{array}$ & $\begin{array}{l}0.55 \\
\bar{C} \\
0.025 \\
\overline{0.18} \\
0.30 \\
0.54 \\
0.08 \\
0.37 \\
0.30 \\
0.14\end{array}$ \\
\hline
\end{tabular}


Table 3 Results of the PMR analysis: stratified by age and job type: (2) production moulders

\begin{tabular}{|c|c|c|c|c|c|c|c|c|}
\hline \multirow[b]{3}{*}{ Cause } & \multicolumn{8}{|c|}{ Age (years) } \\
\hline & \multicolumn{4}{|c|}{$20-64(n=74)$} & \multicolumn{4}{|c|}{$\geqslant 65(n=14)$} \\
\hline & Obs & $\operatorname{Exp}$ & $O / E$ & $\begin{array}{l}\text { Poisson } \\
I \text { sided } p^{*}\end{array}$ & Obs & $\operatorname{Exp}$ & $O / E$ & $\begin{array}{l}\text { Poisson } \\
\text { I sided } p^{*}\end{array}$ \\
\hline All cancer, & 7 & 8.92 & 0.78 & 0.33 & 4 & $2 \cdot 44$ & 1.64 & 0.23 \\
\hline Ca buccal, lip, pharynx & 0 & 0.35 & - & - & 0 & 0.7 & - & - \\
\hline Ca larynx & 0 & $0 \cdot 19$ & - & - & 0 & 0.04 & - & - \\
\hline Ca trachea, bronchus, lung & 2 & $2 \cdot 31$ & 0.87 & 0.59 & 1 & 0.62 & 1.62 & 0.46 \\
\hline Ca oesophagus & 3 & 0.28 & $10 \cdot 87$ & 0.03 & 0 & 0.08 & - & - \\
\hline Ca stomach & 1 & 0.78 & $1 \cdot 28$ & 0.54 & 2 & $0 \cdot 3$ & 6.67 & 0.04 \\
\hline $\mathrm{Ca}$ intestines, rectum & 0 & 0.73 & - & - & $\mathbf{0}$ & $0 \cdot 23$ & - & - \\
\hline Ca prostate & 0 & 0.2 & - & - & 0 & 0.38 & - & - \\
\hline All non-malignant respiratory & 7 & 3.97 & $1 \cdot 76$ & $0 \cdot 11$ & 1 & 1.97 & 0.51 & 0.41 \\
\hline Respiratory tuberculosis & 0 & 0.33 & - & - & 0 & 0.04 & - & - \\
\hline All circulatory & 30 & 28.9 & 1.04 & 0.44 & 5 & 7.65 & 0.65 & 0.23 \\
\hline All poisonings, accidents & 19 & $3 \cdot 2$ & 5.94 & 0.000 & 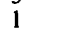 & 0.71 & 1.41 & 0.51 \\
\hline
\end{tabular}

*In the direction of the observed value.

production moulders $(\mathrm{O} / \mathrm{E}=1.04)$ showed reduced PMRs, all of which were non-significant ( $p$ values ranging from $0 \cdot 1-0 \cdot 44$ ).

\section{$R P M R, M O R$, and PCMR analysis}

Table 4 shows the results of the case-control studies comparing the odds ratio when using three different control groups (see methods) and the ratio PMR (journeymen):PMR (production moulders) for malignant and non-malignant respiratory disease. In all instances the odds ratio is raised for both malignant and non-malignant respiratory causes of death regardless of the definition of controls. Owing to low cell sizes none of the results reached statistical significance.

\section{Discussion}

\section{ACCURACY OF DEATH CERTIFICATES}

Death certificate information for South African whites is reasonably accurate and complete. In a study among gold miners information derived from a necropsy compared favourably with the cause of death on death certificates. There was $\mathbf{9 2} \%$ agreement for ischaemic heart disease, $83 \%$ for lung cancer, $72 \%$ for nonmalignant respiratory disease, and $78 \%$ for accidental causes. $^{18}$

\section{COMPLETENESS OF THE COHORT}

Those iron moulders who left the union and subsequently died out of benefit were not followed up. Current publications suggest that a proportion of these may have left due to health reasons because of the particularly arduous nature of this industry. ${ }^{19}$ Subsequently, the data available for analysis may represent a healthier subset of the full cohort. A bias may also be present regarding job and disease ascertainment. Overall PMRs stratified by age and job type are higher than those stratified by age alone. The direction of this bias is not fully understood but may be related to the completeness of information related to causes of deaths assumed to be associated with a particular job type.

\section{PMR STUDY}

The increased PMR for lung cancer and respiratory

Table 4 Odds ratios (and two tailed probability values) using different control groups

\begin{tabular}{|c|c|c|c|c|}
\hline Age stratification & $P M R_{J M}: P M R_{P M}(R P M R)$ & $\begin{array}{r}\text { Lung cancer } \\
\text { All other causes }(M O R i)^{*}\end{array}$ & $\begin{array}{l}\text { All other causes excluding } \\
\text { respiratory diseases }(M O R \text { ii) }\end{array}$ & All other cancers (PCMR) \\
\hline $\begin{array}{l}20-64 \\
\geqslant 65\end{array}$ & $\begin{array}{l}1 \cdot 31(0 \cdot 19) \\
1 \cdot 20(0 \cdot 39)\end{array}$ & $\begin{array}{l}2 \cdot 01(0 \cdot 19) \\
1 \cdot 20(0 \cdot 39)\end{array}$ & $\begin{array}{l}2 \cdot 07(0 \cdot 19) \\
1 \cdot 38(0 \cdot 38)\end{array}$ & $\begin{array}{l}1.92(0.28) \\
2 \cdot 76(0.52)\end{array}$ \\
\hline \multicolumn{5}{|c|}{ Respiratory disease } \\
\hline Age stratification & $P M R_{J M}: P M R_{P M}(R P M R)$ & All other causes $(M O R i)^{*}$ & $\begin{array}{l}\text { All other causes excluding } \\
\text { lung cancer (MOR ii)* }\end{array}$ & $\begin{array}{l}\text { All other cancers excluding } \\
\text { lung cancer (PCMR) }\end{array}$ \\
\hline $\begin{array}{l}20-64 \\
\geqslant 65\end{array}$ & $\begin{array}{l}0.94(0.77) \dagger \\
2.65(0.31)\end{array}$ & $\begin{array}{l}1 \cdot 26(0 \cdot 78) \dagger \\
2.91(0 \cdot 20)\end{array}$ & $\begin{array}{l}1 \cdot 3(0 \cdot 13) \dagger \\
3 \cdot 0(0 \cdot 19)\end{array}$ & $\begin{array}{l}1 \cdot 21(0.26) \\
2 \cdot 0(0.46)\end{array}$ \\
\hline
\end{tabular}

* See methods section.

†These used the chi-squared test ( $1 \mathrm{df}$ ) with continuity correction. In all others Fishers exact test, two tailed probabilities were used. 
disease in the older iron moulders is consistent with most other studies concerned with occupational exposure to foundry environments. ${ }^{11}{ }^{120-25}$ In one particular PMR study among foundrymen the overall lung cancer PMR was 1.44 and the overall PMR for respiratory disease was $1 \cdot 38 .^{12}$ The lowered PMR for circulatory disease is also consistent with other studies suggesting that strong selective effects operate in this industry. A striking difference between this and other studies is the high PMRs for injuries and poisonings in the younger iron moulders - that is, those who died before age 65. In the PMR study referred to above the PMR for accidents was 78.

RPMR, MOR, AND PCMR ANALYSIS

Control groups are usually chosen depending on the aims of a particular study and the state of the art knowledge about the effect of a particular exposure on other causes of death. The use of different referent populations had a small but variable effect on the odds ratio for lung cancer and for respiratory disease. At the same time there is an increase in random variation, with none of the comparisons reaching statistical significance. In all except one instance the MOR and PCMR odds ratios exceeded the RPMR odds ratio.

\section{SMOKING AS A CONFOUNDER}

Smoking cannot fully explain the increased PMRs for several reasons: there are no increases in PMRs in other related causes of death such as circulatory disease; a considerably larger proportion of smokers must be present in a cohort to make a significant contribution to the odds ratio and, finally, SMRs (in this case the approximation could hold for PMRs) exceeding 150 cannot be explained by increases in smoking alone. ${ }^{2627}$

\section{Conclusion}

This study has shown that certain age classes of iron moulders are at increased risk of respiratory disease and lung cancer when compared with the general population. This finding is consistent with world publications on the effects of occupational exposure to foundry environments and inconsistent with the hypothesis that the excess PMRs are due to excess smoking in this cohort. The increased risk of respiratory disease and lung cancer among journeymen when compared with production moulders is poorly understood, and could be artifactual owing to the relatively small differences in the odds ratio and the low statistical significance between the two job types.

A high PMR for injuries and poisonings is consistent with the iron and steel industry's high accident fatality rate. ${ }^{28}$ This warrants further investigation as the ICD codes in this study did not distinguish between industrial and non-industrial accidents.

Several people and organisations were key to the success of this study: the IMS, especially $\mathrm{Mr} \mathrm{C} \mathrm{J⿳亠丷厂巾}$ Bronkhorst, and Mrs L Owen for facilitating the extraction of the relevant information, Professor Margaret R Becklake, Basil Bezuidenhout, Professor $\frac{\bar{m}}{\frac{1}{b}}$ J C A Davies, Sir Richard Doll, Mandy Hobbs, $\stackrel{\odot}{\odot}$ Gina Joubert, Danuta Kielkowski, Susan Landau, David Leon, Linda Malekela, Ann Mullins, Gill Reid, Martin Shipley, Dr G K Sluis-Cremer, and. Derek Yach. This study was assisted by the Medical $\vec{\overrightarrow{ }}$ Research Council of South Africa and the Medical ${ }^{\omega}$ Research Endowment fund of the University of the Witwatersrand, Johannesburg, South Africa.

\section{References}

1 Schimberg RW, Pfaffli P, Tossavainen A. Polycyclic aromatic hydrocarbons in foundries. J Toxicol Environ Health1980;6:1187-94.

2 International Agency for Research on Cancer. Evaluation of the carcinogenic risk of chemicals to humans. Vol 34, part 3. Lyon: IARC, 1984.

3 National Institute for Occupational Safety and Health. Recommendations for control of occupational safety and health: hazards. . . foundries. Vol 85.116. Cincinnati:NIOSH, 1985.

4 Palmer WG, Scott WD. Lung cancer in ferrous foundry workers: a review. American Industrial Hygiene Association Journal 1981;42:329-40.

5 Decoufle P, Thomas T, Pickle L. Comparison of the proportional mortality ratio and the standardised mortality ratio risk measures. Am J Epidemiol 1980;111:263-9.

6 Axelson 0 . The case referent (case-control) study in occupational health epidemiology. Scand J Work Environ Health 1979;5:91-3 9.

7 Miettinen O, Wang JD. An alternative to the proportionalo mortality ratio. Am J Epidemiol 1981;114:144-8.

8 Walter SD. Cause deleted proportional mortality analysis and the healthy worker effect. Statistics in Medicine 1986;5:61-71.

9 Axelson O, Dahlgren E, Jannson CD. Arsenic exposure and mortality: a case-referent study from a Swedish copper smelter. 3 Br J Ind Med 1978;35:8-15.

10 Koskela RS, Hernberg S, Karava R, Jarvinen E, Nurminen M. A 응 mortality study of foundry workers. Scand J Work Environ Health 1976;2(suppl 1):73-89.

11 Fletcher AC, Ades A. Lung cancer mortality in a cohort of English foundry workers. Scand J Work Environ Health 1984;10:7-16. I

12 Egan-Baum E, Miller BA, Waxweiler RJ. Lung cancer and other 음. mortality patterns among foundrymen. Scand $J$ Work Environ Health 1981;7(suppl 4):147-55.

13 Webster EC. Cast in a racial mould. Labour process and trade N unionism in the foundries. Johannesburg: Ravan Press, 1986.

14 Lewis J. Industrialisation and trade union organisation in South $\mathrm{W}$ Africa, 1924-1955. Cambridge: Cambridge University Press, 1986.

15 Anonymous. South African Foundry log. Foundry Welding and Production Journal. 1982;November:85-116.

16 Coleman M, Douglas A, Hermon C, Peto J. Cohort study analysis with a fortran program. Int J Epidemiol 1986;15:134-7.

17 Breslow NE, Day NE, Davis W. Statistical methods in cancer research. Vol 1. The analysis of case-control studies. Lyon: $\frac{\text { Tे }}{\square}$ International Agency for Research on Cancer, 1980. (IARC sci publ No 32.) 
18 Wyndham CH, Bezuidenhoud BN, Greenacre MJ, Sluis-Cremer GK. Mortality of middle aged South African gold miners. Br J Ind Med 1986;43:677-84.

19 Koskela RS, Jarvinen E, Korhonen E, Mutanen P. Health selection among metal workers. Scand J Work Environ Health 1983;9:155-61.

20 Tola S, Koskela RS, Hernberg S, Jarvinen E. Lung cancer mortality among iron foundry workers. J Occup Med 1979;21:753-60.

21 Lloyd JW, Lundin FE, Redmond CK, Geiser PB. Long term mortality of steelworkers. IV. Mortality by work area. J Occup Med 1970;12:151-7.

22 Decoufle P, Wood DJ. Mortality patterns among workers in a grey iron foundry. $A m J$ Epidemiol 1979;109: 667-75.
23 Gibson ES, Martin RH, Lockington JN. Lung cancer mortality in a steel foundry. J Occup Med 1977;19:807-12.

24 Vena JE, Sultz HA, Fiedler RC, Barnes RE. Mortality of workers in an automobile engine and parts manufacturing complex. $\mathrm{Br} J$ Ind Med 1985;42:85-93.

25 Assenato G, Mollinini R, De Nicolo M, Di Gaetano O, Ferri G. Long term mortality study among steel workers. Med Lav 1986;77:120-1.

26 Steenland K, Beaumont J, Halperin W. Methods of control for smoking in occupational cohort mortality studies. Scand $J$ Work Environ Health 1984;10:143-9.

27 Doll R. Occupational cancer: problems in interpreting human evidence. Ann Occup Hyg 1984;28:291-305.

28 South African Workmens' Compensation Commissioner. Annual Accident Statistics. Pretoria: Government Printer.

\section{Destruction of manuscripts}

From 1 July 1985 articles submitted for publication will not be returned. Authors whose papers are rejected will be advised of the decision and the manuscripts will be kept under security for three months to deal with any inquiries and then destroyed. 